\title{
Environment Sustainability in the Age of Digital Revolution: A Review of the Field
}

\author{
Ali M. Al-Khouri \\ Director General, Emirates Identity Authority, United Arab Emirates
}

\begin{abstract}
The world today has been witnessing phenomenal outgrowth in all fields during the past few decades. This augmentation has been largely stimulated by information and communication technologies (ICT). However, the inexorable evolution of technology and global economic development are being pursued at an ever-increasing societal cost with a snowballing potentially negative impact on the environment. Hence, one of the important challenges modern society faces is sustainability. This article attempts to explore the existing body of knowledge to provide a better understanding of the impact of ICT and digital revolutions on global carbon footprint and emissions. It also attempts to explore the presence of environmental sustainability initiatives in e-government programs worldwide. It presents some thoughts about how governments may address sustainability requirements in their egovernment programs and enact responsible ICT-enabled transformation.
\end{abstract}

Keywords: environment; sustainability; e-government; low-carbon environment

\section{Introduction}

With the deterioration of the planet's ecosystems along with climate change and global warming becoming the "hot" topics of the 21 st century, information and communication technologies (ICT) are envisaged to play a significant role in reducing the global carbon footprint and emissions while maintaining economic growth and improving people's quality of life worldwide. Accordingly, sustainability is rapidly becoming a leading priority for organizations worldwide to improve energy efficiency and to reduce consumption.

Sustainability in simple terms refers to the capacity to endure. It is about the "development that meets the needs of the present without compromising the ability of future generations to meet their own needs" (Brundtland, 1987).

In short, the term "sustainability" mandates respecting environmental limits while fulfilling social wants and needs. It stands on the reconciliation of the three primary pillars of environmental (protecting and restoring ecological systems), social equity (enhancing the well-being of all people), and economic demands (improving economic efficiency), also referred to as the three pillars of sustainability (United Nations [UN], 2005).

The international Union of Conservation of Nature (IUCN) illustrated the relationships among these three components of sustainability using overlapping circles, as depicted in Figure 1 (IUCN,
2012). See also Barton (2000), du Plessis (2000), Hardi and Zdan (1997), ICLEI (1996). The IUCN model attempts to demonstrate the theoretical, current, and needed auctioning change to redress the balance among the three dimensions of sustainability. New studies suggest the need to develop policy frameworks that leverage ICT to achieve sustained growth and long-term societal benefits (Arnaud, 2012; Souter et al., 2013). Other studies suggest massive social, political, technological, cultural, and behavioral change to support such a transition, with environmental sustainability being a key focus area (Mansell, 2012; Vickery, 2012).

In most debates and examinations of sustainable development, either the environment or the economy is given priority (Giddings et al., 2002). Such a view of separation among sectors typically produces a technical fix approach (e.g., lowering resource use through taxation, etc.), but it is likely to distract governments or institutions from tackling the deeper issues or from seeing the connections among society, economy, and the environment.

Although many countries have initiated policies on global1 and local levels to address sustainability needs, those policies are being challenged. The challenges are often about balancing the need to grow economies while at the same time ensuring that resources are not depleted for future generations (Infocommunications Development Authority of Singapore [iDA], 2012).

Print ISSN 2329-0781 - Online ISSN 2329-079X / World Scholars http://www.worldscholars.org 
This article's purpose is to contribute to a better understanding of the impact of ICT on global carbon footprint and emissions. It attempts to offer some thoughts regarding how governments may address sustainability requirements in their e-government programs and enact responsible ICT-enabled transformation. It also attempts to explore the presence of environmental sustainability initiatives in egovernment programs worldwide. Based on the review of the field, the article presents some thoughts for governments to consider for the most responsible egovernment and ICT-enabled transformation.

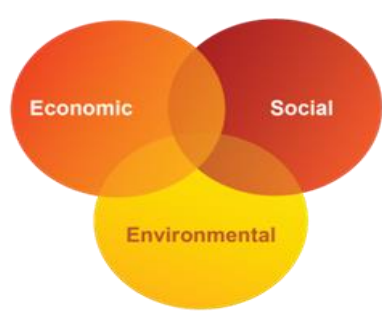

THE THEORY

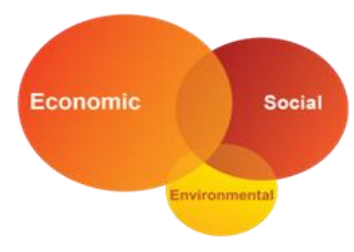

NOW

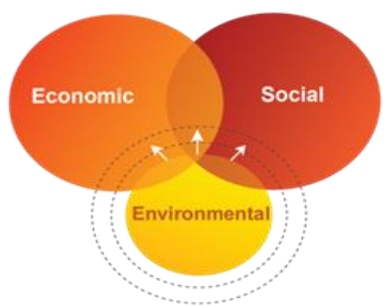

THE CHANCE NEEDED

Figure 1: The interlocking circles of the three pillars of sustainability. Source (IUCN, 2012).

\section{ICT: The Problem or the Solution?}

Unquestionably, the digital revolution and advances in ICT have re-shaped our world in terms of how we communicate and do business. With all of its contributions, ICT is also viewed as being behind increasing socio-economic inequality and environmental damage (Matthews, 2001; Ogbom et al., 2012). Although ICT can contribute to enabling a low-carbon economy, the energy and carbon impact of the sector itself is considered to be significant (Schluepa et al., 2009).
All in all and as the ICT sector continues to grow, the energy consumption and carbon emissions are also growing. The rapid growth of Internet use and the emissions generated from online activity are argued to vary considerably depending on the efficiency of operations and the type of energy used (Foster, 2013). For instance, the carbon footprint of one Google search is equivalent to an 11-watt light bulb that operates for one hour. This should be an issue if we realize that Google processes 100 billion queries every month. See also Figure 2.

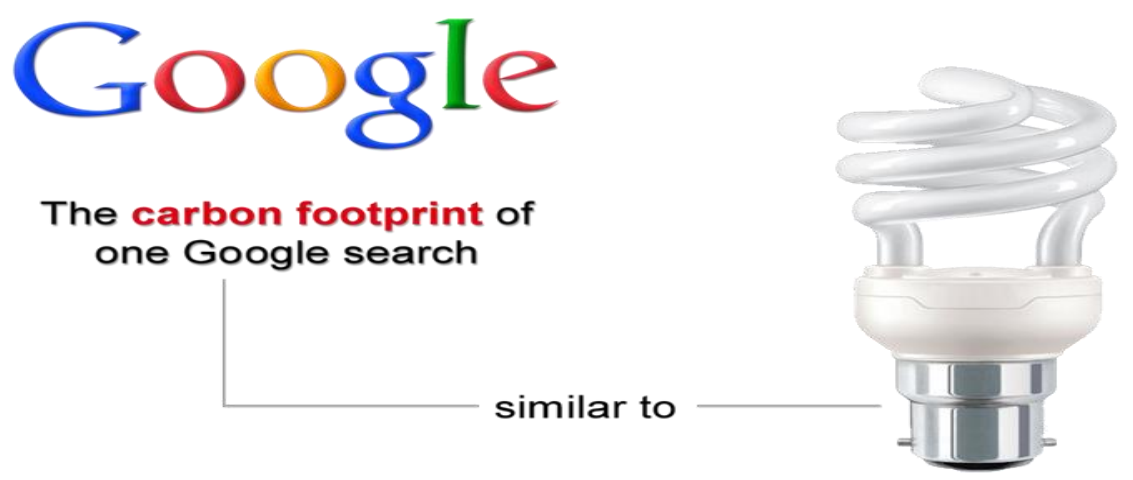

Figure 2. Google's environmental footprint.

On a different note, an increasing demand for computing resources during the past few years has led, in turn, to significant growth in the number of data centers that support e-government and ICT initiatives. This has resulted in an estimated doubling in the energy that the servers use and the power and cooling infrastructure that supports them (Quintiliani et al., 2010). According to Forrester Research, a data center with 1,000 servers will use enough electricity in a single month to power 16,800 homes for a year (Burris et al., 2011). 
According to a recent report from the Centre for Energy-Efficient Telecommunications at the University of Melbourne, by 2015, the energy used to run data centers will be a "drop in the ocean" compared with the wireless networks used to access cloud services (Centre for Energy-Efficient Telecommunications [CEET], 2013). The report predicts the energy use of cloud services accessed via wireless networks to grow up to $460 \%$ between 2012 and 2015, the equivalent of 4.9 million new cars on the roads.

Another fact related to ICT in this regard is regarding its short lifetime. The fast development pace of today's technologies is constantly shortening electronic devices' lifespans. The ever-growing flow of e-waste as a result is reported to be between 20 million tons to 50 million tons produced each year; e.g., computers, televisions, videocassette recorders (VCRs), stereos, copiers, and fax machines are common electronic products (Schluep et al., 2006).

Recent statistics show that the United States (US) discards 30 million computers each year (Gupta, 2012). A total of 100 million phones are discarded each year in Europe (Begum, 2013). It is forecasted that e-waste worldwide could rise by $500 \%$ within the next 10 years in some countries such as India, according to a recently released United Nations Environmental Program (UNEP) report (UNEP, 2009).

Most of the e-waste is exported to developing countries, where it is hidden under the umbrella of charity: "computers for the poor" and the like (Hull, 2010; Luther, 2010). Interestingly, 70\% of global ewaste is dumped in China, with most of the rest going to India and to African nations (Liu et al., 2006). Meanwhile, a total of $15-20 \%$ of e-waste is recycled, while the rest of these electronics go directly into landfills and incinerators (Sthiannopkao \& Wong, 2012). In light of the informal processing procedures that countries follow coupled with a lack of clear standards, the consequences of such practices have the potential to cause serious health issues and to contribute to greater pollution problems (Robinson, 2009).

Although recent studies admit the significant increase of the ICT carbon footprint, they refer to the fact that the sector is causing only about $2 \%$ of global carbon dioxide (CO2) emissions - as much as air transport - and that its benefits override its tribulations in multifold (Gartner, 2009).

The International Telecommunication Union (ITU) has estimated the contribution of ICTs (excluding the broadcasting sector) to climate change to be between $2 \%$ and $2.5 \%$ of total global carbon emissions (ITU, 2009). The main contributing sectors within the ICT industry include the energy requirements of personal computers (PCs) and monitors (40\%), data centers, which contribute a further $23 \%$, and fixed and mobile telecommunications that contribute $24 \%$ of the total emissions (Dunn, 2010).

Although ICT's footprint is projected to rise to 1.27 (2.3\%) of Global Total Emissions [GtCO2e] by 2020, proponents indicate that its abatement potential is seven times higher. See also Figure 3. They argue that ICT could reduce global carbon emissions through efficiency gains across sectors worldwide and is viewed as a high-impact sector in global efforts to address climate change.

In addition, it is argued that ICT can play a key role in calculating, monitoring, optimizing, and managing domestic and industrial energy usage and in reducing ICT-related emissions globally. International reports indicate that ICT could save nearly \$1.9 trillion in 2020 and that 29.5 million jobs would be created worldwide as a result (Global e-Sustainability Initiative [GeSI], 2012).

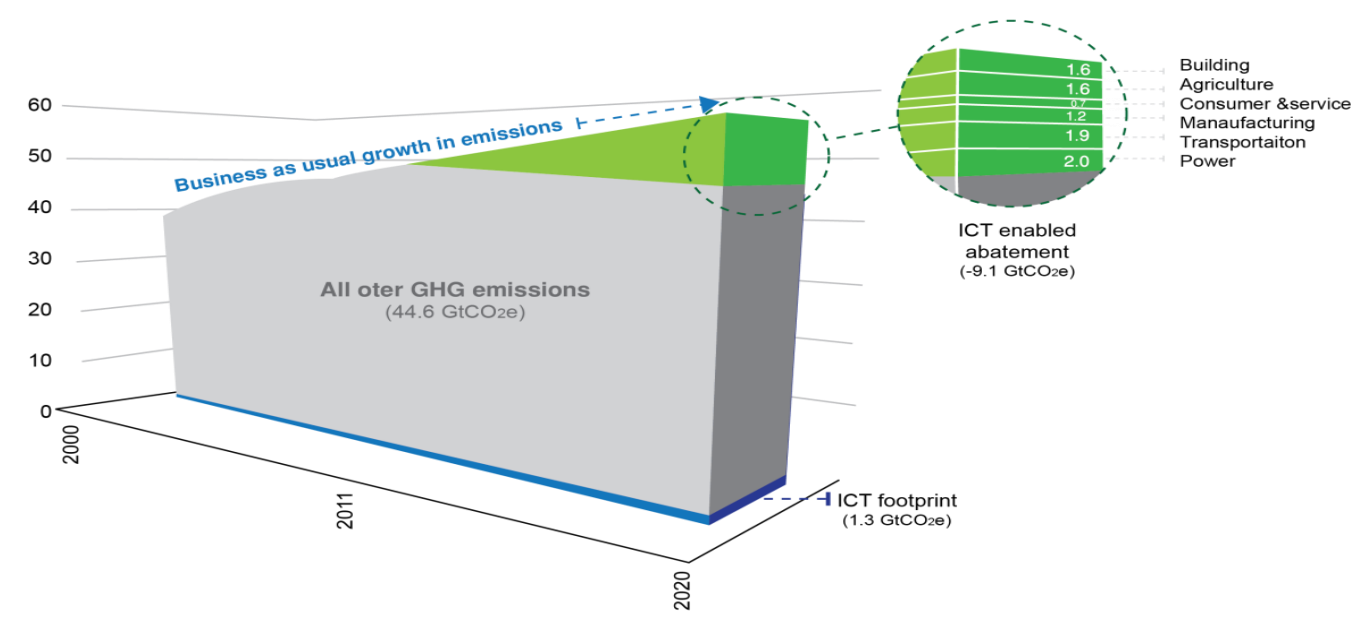

Figure 3: Abatement potential in 2020 plotted with the direct emissions from the ICT industry and total global GHG emissions. Source: (GeSI, 2012). 
Adversaries emphasize that the ICT industry's responsibility should be viewed as going well beyond facilitating the greening of other industries and enterprises and should rather focus on examining the role of ICT in climate change as well as the disposal of ICT waste (Dunn, 2010; Hull, 2010; Robinson, 2009).

From a different perspective, international institutions also refer to the fact that production that has a far greater impact on sustainability should not be considered in isolation from consumption (Strange and Bayley, 2008). Although electronic products and services are the shining side of ICT, it is essential to examine the trends and interactions between consumption and production (ibid.). Simply put, the virtual (or digital) economy has physical foundations, and digital products use resources and create waste.

Let us see the relation between production and consumption in the following examples. Emissions from the manufacturing and use of PCs alone will double over the next 12 years as middle-class buyers in emerging economies go digital (Boccaletti et al., 2008). Similarly, worldwide growth in the use of mobile phones will triple its carbon footprint by 2020, due in large to their consumption of silicon and rare metals. However, the fastest-increasing contributor to carbon emissions will be as a result of growth in the number and size of data centers, whose carbon footprint will rise more than fivefold between 2002 and 2020 as organizations in all sectors add servers to meet rising demand even as companies and governments alike attempt to become more energyefficient (Boccaletti et al., 2008).

In general terms, the present concepts of sustainability and sustainable development are clearly inadequate to drive the transitions necessary to adapt human relations with the rest of the biosphere for the future (Adams, 2006). As currently formulated, they are too loose to drive effective change on the scale required (ibid).

Having said that, the next section attempts to explore environmental sustainability practices in the context of e-government and to discuss their implications for practitioners and researchers.

\section{E-government and Sustainability}

E-Government can be defined broadly as a service delivery engine that allows services to be requested and delivered over various electronic channels by enabling a connected government, thus resulting in allaround efficiencies in government operations. It is increasingly being seen as the answer to a plethora of problems that governments or public agencies in general face in serving their constituencies effectively (Kumar and Best, 2006). Various terminologies and benefits are associated with e-government, as depicted in Figure 4.

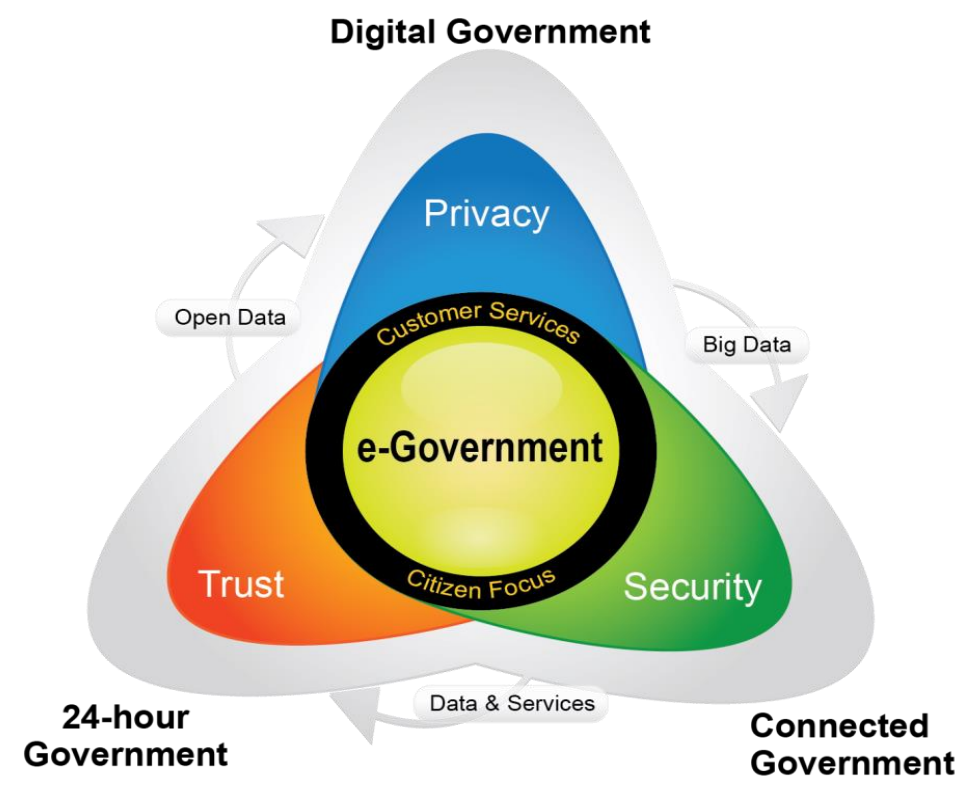

Figure 4: e-Government context 
In principle, e-government is not limited to the often quoted services, convenience, availability, etc., but can rather have a big impact on the socio-economic landscape and on environmental sustainability-all three pillars of sustainability. It has a direct impact on time-saving in transactions and in interactions that contribute to potentially millions of dollars of productivity increase. Typically, productivity increases due to the redeployment of resources to the information and knowledge domains that contribute to socio-economic demographics. Add to this the savings in costs due to transportation obviated by the need to visit government offices, the numbers compound themselves in savings to governments and to reduction in fossil fuel usage.

E-government contributes to the reduction of paper by removing the need to complete and submit cumbersome application forms. This further reduces the need for processing papers, storing, and making copies of them, thus contributing to further reduction of physical paper and hence storage.

Nonetheless, and although considerable attention has been focused on how e-government can help public agencies to improve their services, relatively few studies focus on how e-government programs are architected to facilitate low-carbon environments (Cohen, 1999; Cormier and Magnan, 2004; Devuyst and Hens, 2000; Haigh and Griffiths, 2008). Environmental sustainability is the soundless side in egovernment initiatives. It comes as a rather surprising observation that in spite of such obvious environmental factors that e-government initiatives have addressed well, governments have failed in their strategic endeavors to include environmental sustainability and conservation in their e-government efforts. In addition, a dilution and misalignment of national government environmental strategies exist in e-government initiatives. Various research studies support our findings that governments have failed in their strategic endeavors to include environmental sustainability in their e-government efforts (Krishnan and Teo, 2011; Nishant et al., 2013).

Let us have a look at a recent report from the Organization for Economic Cooperation and Development (OCED), which examines e-government initiatives throughout the world (OCED, 2011). Figure 5 depicts the general objectives of e-government, mainly related to a reduction in administrative overheads, the cost reduction of government operations, and responsiveness to citizen needs.

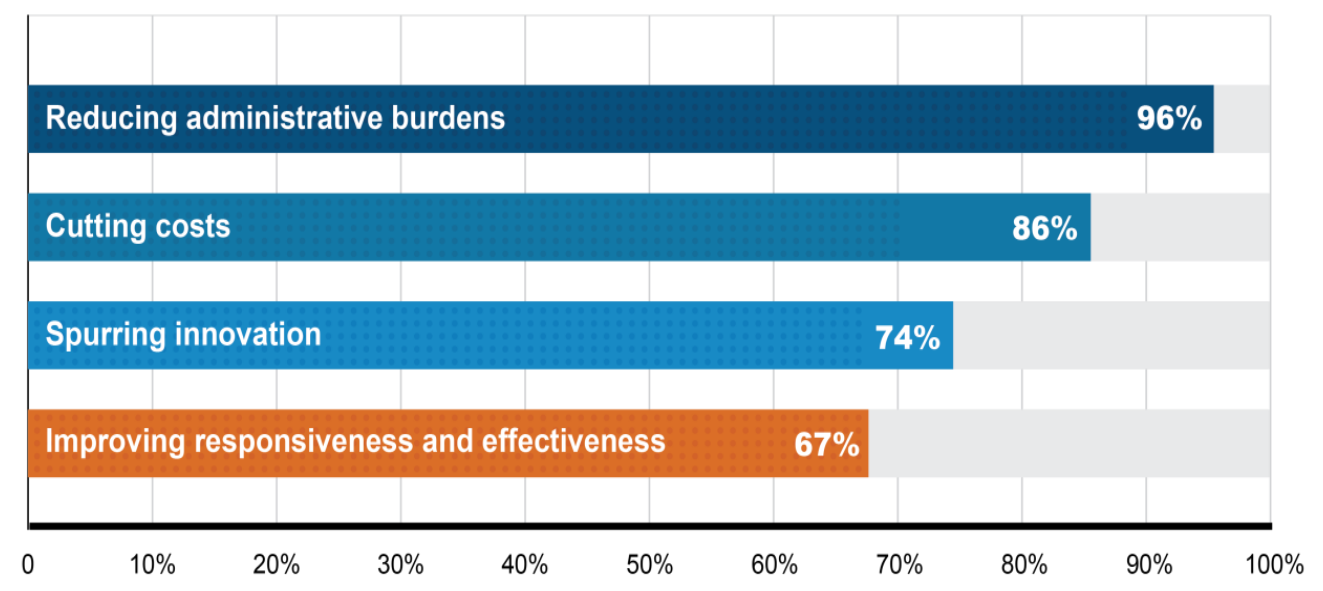

Figure 5: Top e-government objectives identified in central government (2010). Source: (OCED, 2011)

Figure 6 depicts the associated e-government initiatives. Interestingly, none of the initiatives include environment-related functions. This is hardly surprising since the underlying policies and laws in egovernment programs that drive these objectives do not include environmental strategies. 


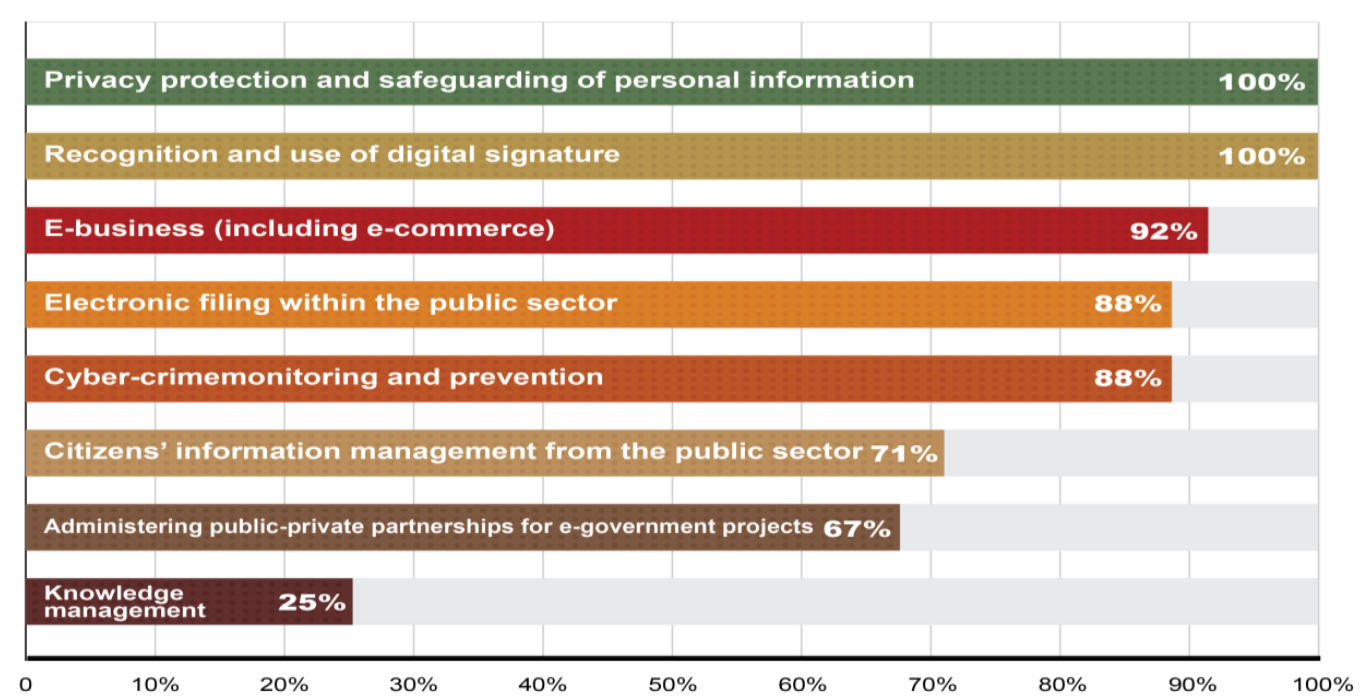

Figure 6: Central government initiatives that enable e-government. Source: (OCED, 2011).

Why exactly do we have this misalignment? The results of a study by Haigh and Griffiths (2008) indicate that while positive environmental outcomes were sought at higher-level e-government strategies, they dissipated as they made their way down to the e- government strategy implementation level. The authors also presented an illustrative framework of four layers in an effort to explain their point, as depicted in Figure 7.

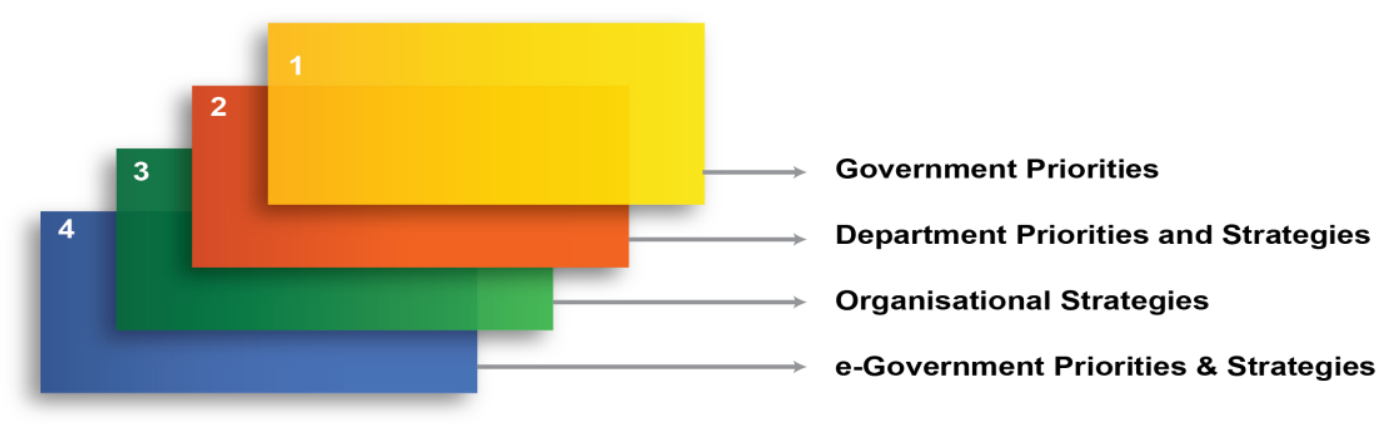

Figure 7: Government strategy framework

Layer 1 in the framework depicts government priorities at a national level. Priorities at this layer have large considerations and include strategic initiatives on the environment sustainability. At the next level of departmental priorities, at the implementation stage, the strategic intents become diluted, although clear initiatives exist under a green environment. At the operational level of organization, where the operational requirement drives strategies more than do national requirements, the environmental considerations become diluted substantially. At the last level of e-government strategies, the environmental considerations are virtually nonexistent.
A recent study conducted to investigate environmental sustainability outcomes associated with implementing information systems in Australian government organizations supported the findings of Haigh and Griffiths (2008). Service quality improvements were observed to be a more compelling strategic issue for the organizations, and environmental sustainability outcomes were not sought at the organizational levels and thus not fulfilled at the operational level.

Another study conducted by Nishant et al. (2013) found that empirical support exists for the negative relationship between sustainable IT practices and emissions. The study indicates that organizations 
basically need to work more collaboratively in order to derive maximum benefits from information obtained about the direct and indirect emissions of their IT initiatives.

Kumar and Best (2006), building on the work of Heeks and Bhatnagar (1999), proposed a number of critical success/failure factors that may explain the adverse relationship between e-government programs and environmental sustainability. These factors are depicted in Table 1.

Table 1. e-Government Success and Failure Factors.

\begin{tabular}{lll}
\hline Kumar and Best (2006) Critical Failure & Heeks and Bhatnagar (1999) Factors \\
\hline - Training & $\bullet$ People factor \\
- Sustained leadership, institutionalization & - Management, cultural, structural factors \\
- Evaluation and monitoring & $\bullet$ Process and management factors \\
- Power shift & $\bullet$ People, management, cultural, structural factors \\
\hline
\end{tabular}

Kumar and Best (2006) indicated that public managers should clearly understand the importance of their leadership role in the development and institutionalization of the low-carbon environmental initiatives. They should also focus on the cost/benefit analysis to measure the environmental footprint of main and sub e-government initiatives, both direct and indirect, from production and consumption viewpoints as well.

Zadek (2011) stated that technology providers and users need to have a stake in such initiatives. However, first, governments need to comprehend that a practical, communication, and policy gap currently exists among public awareness, ICT usage, and low-carbon agendas.

All in all, e-government initiatives need to reflect national government environmental priorities. If egovernment initiatives are not regulated from an environmental perspective, they will potentially result in counter-productive and misaligned initiatives.
E-government by design contributes to the development of virtual environments: electronic transactions that lead to the generation of lots of content. However, if this content is not managed with a clear policy or with the intention of being printed again for archival reasons, for example, the very purpose of environment conservation and sustainability would be defeated. Another example would be in the use of electronic channels and the devices. All electronic devices consume power, although with variances. Inefficient devices consume more power and are counter-productive to environmental sustainability. Governments need to work more effectively to demonstrate their ability to deliver large savings in energy consumption. Figure 8 shows that the use of more efficient technologies have the potential to cut electricity consumption by an estimated $30 \%$ in 2030, compared with the businessas-usual scenario $(2009)^{2}$.

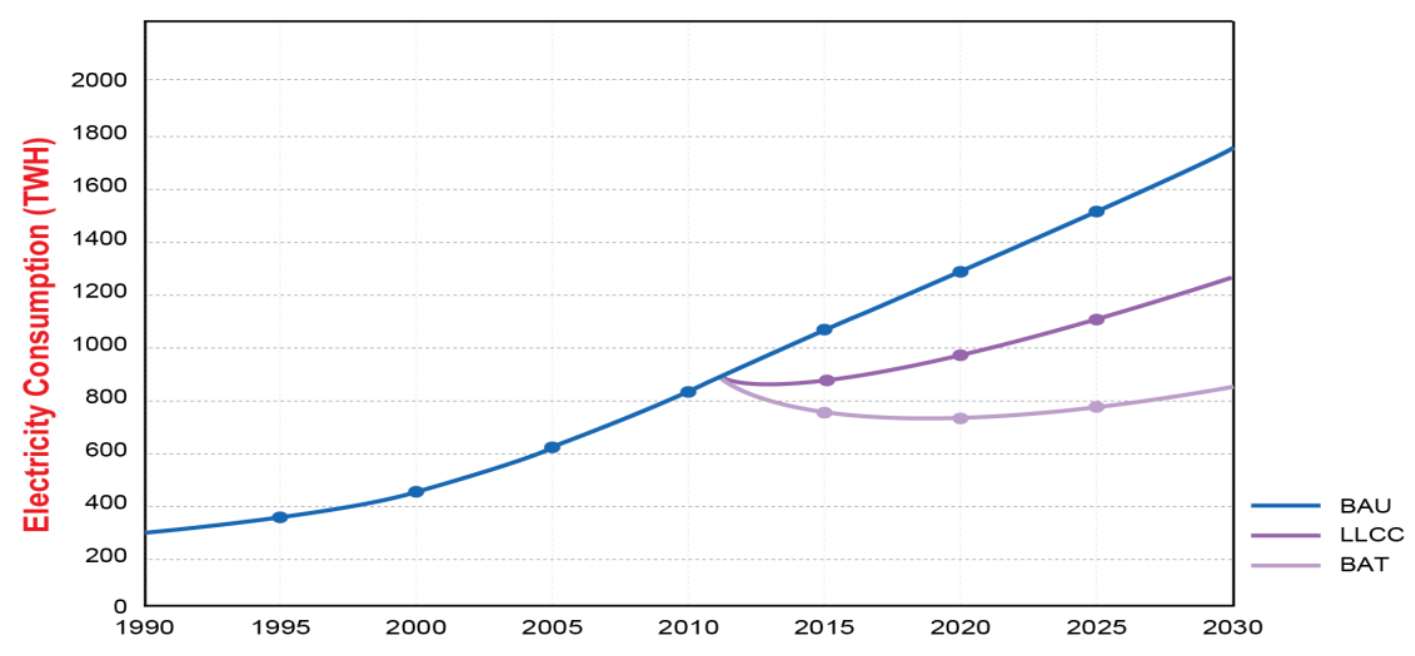

Figure 8: Estimated electricity savings from adoption of least life-cycle cost (LLCC) and best available technologies (BAT). Source: (IEA, 2009) 
E-government programs also rely on high-tech and large data centers for enabling virtual and electronic environments. Governments need to re-evaluate the ICT infrastructure to minimize inefficient power consumption, i.e., badly designed data centers may increase energy usage, while poorly designed or overdesigned servers and storage may also lead to the same results. Governments need to work more effectively to demonstrate their ability to deliver large savings in energy consumption.

Several other such examples that could be cited include the disposal or rather unregulated disposal of devices such as desktops, laptops, and mobile phones, which may contribute to major land pollution disasters. Governments need to develop clear policies to regulate the disposal of devices, especially in relation to the overall management of e-waste.

Definitively, it is imperative that governments need to examine their e-government programs and initiatives in the context of environment sustainability. They need to focus on redressing the increasing carbon footprints that stem from high-energy infrastructures and applications, such as call centers, cloud computing data centers, ultra-fast servers, complex telecommunications networks, equipment-cooling devices and expensive air conditioning, the use of multiple PCs, powerful modems, and ubiquitous mobile phones (Dunn, 2010).

Two of the areas to which governments need to pay attention in their overall e-government design strategies are related to (1) cloud services and (2) shared resources:

- Cloud Services: Government initiatives to move to the cloud may substantially contribute to hardware (servers) consolidation and efficiency improvements in the delivery of service.

- Shared Resources: From a government perspective, national data centers as shared data centers should be considered in order to reduce the burden of individual data centers. This obviates the need for individual data centers for each department and ensures higher productivity in service provisioning. This approach is being followed in South Korea and India.

In short, environmental sustainability must be defined as a key and strategic pillar in the overall egovernment and ICT production and consumption equilibrium. E-government initiatives and programs need to adhere to national and international policies and frameworks for sustainable development. National strategies related to environmental sustainability need not only to focus on idiosyncratic descriptive measures, but must focus on the set of functions and on promoting a coherent effort in establishing mechanisms to ensure effective implementation and anticipated outcome realization.

\section{Conclusion}

Without a doubt, ICTs and e-government programs by design contribute positively to both socio-economic and sustainable development. It is imperative that egovernment strategies and objectives need to explicitly include environmental sustainability as a key strategic objective. Such alignment must happen at a national level and must be monitored at implementation levels for efficiency and effectiveness. It needs to be managed diligently across all of the layers of strategic prioritization, i.e., laws, policies, regulations, compliance, etc.

Governments today give less attention to how their agencies develop e-government services and have little or no awareness of how they were designed in principle. Governments need to create a mindset that establishes linkage between consumption and production. In light of the gigantic investments in technological development, governments need to be aware of their practices' impacts with relation to environmental sustainability.

Governments have to identify the critical relations among the many factors that are likely to shape economic, social, political, and environmental quality. These elements need to be viewed together but not in isolation. Governments need to find a balance between the need to improve the quality of life of their people and addressing the demand for increased ICT access and services provisioning. However, simultaneously, governments need to work harder to reduce the overwhelming environmental footprint of their current practices and the environmental impact associated with evolving ICT use. This should also be balanced with the environmental impacts (positives and negatives) associated with such needs.

Leadership at the national level is one key element. Furthermore, strategies that are seen as simply one more government program imposed from above have less of a chance of succeeding than do those defined through consultation and debate (Zadek, 2011). Such strategies need to be developed based on the use of local human resources in the context of social equity and sustainable socio-economic and environmental development.

Governments need to establish sound policies and incentivizing practices alongside tough environmental regulations in order to align e-government objectives with social requirements for the more environmentally responsible use of ICTs (Dunn, 2010). Such incentives need to be followed by vibrant targets and rules in order to promote the development of sustainable egovernment models.

Governments clearly need to work together at both national and international levels to create standards and practices in relation to ICT usage in 
different sectors. Such policies and standards need to be rigorous enough to be effective, but they also must be flexible enough to be adapted as circumstances and priorities evolve (Kuhndt et al., 2003; Strange and Bayley, 2008). This should be seen as a critical activity for supporting the transition toward a lower-carbon world and in order to improve the quality of life for impoverished and underserved communities of people worldwide while simultaneously reducing our overwhelming environmental footprint.

The bottom line is that environmental sustainability cannot be left to individual countries, organizations, and persons. Rather, governments need to work together more seriously to systematically react to changing needs and changing social and environmental pressures. Without this, the game of "Is it the chicken or the egg?" will keep surfacing as accountability is lost between the complex ecosystem of stakeholders.

\section{Notes}

1. Globally, numerous international protocols and conventions on sustainable development exist, such as the Kyoto Protocol and the Copenhagen Accord, where nations come together to agree on meeting goals related to cutting carbon emissions as well as establish mechanisms to accelerate technology transfer in an effort to tackle climate change (iDA, 2012). Also, numerous national and local-level strategies exist in almost all countries throughout the world. However, a primary question remains about the effectiveness of such policies.

2. The American Society of Heating, Refrigerating and AirConditioning Engineers (ASHRAE) is a standards-publishing organization for specifications for green buildings. Many data centers and buildings adopt these standards now for the green environment. They specify the air conditioning and heating requirements based on different cooling systems. Further, data centers use a very crucial index to determine "green efficiency" as power utilization efficiency (PUE). This is the ratio of the total power used in a data center/ICT Load. PUE shows how well a data center has been defined. All of the supporting equipment (such as pumps, blowers, motors, heat exchangers, UPS, etc,) that are used in the data centers consume power. Ideally, PUE should be about 1.2 and go up to an acceptable 1.7. This means that the auxiliary equipment that is used for the data centers should consume no more than $70 \%$ max of the power that the ICT equipment uses. It is estimated that $80 \%$ of data centers in the world have a PUE of 2.5 and above. See also ASHRAE (2009).

\section{References}

Adams, W.M. (2006). The Future of Sustainability: Re-thinking Environment and Development in the Twenty-first Century. Report of the IUCN Renowned Thinkers Meeting, 29-31 January 2006. Retrieved from: http://cmsdata.iucn.org/ downloads/iucn_future_of_sustanability.pdf

Arnaud, B.S. (2012). Using ICT for Adaptation Rather Than Mitigation to Climate Change. The International Institute for Sustainable Development. Retrieved from: http://www.iisd.org/pdf/2012/com_icts_starnaud.pdf

ASHRAE. (2009). Proposed Standard 189.1P, Standard for the Design of High-Performance Green Buildings Except Low-
Rise Residential Buildings, American Society of Heating, Refrigerating and Air-Conditioning Engineers, Inc., Atlanta, GA. Retrieved from: https://osr.ashrae.org/ Public\%20Review\%20Draft\%20Standards\%20Lib/189.1P_3 rd_PPRDraft.pdf

Brundtland, B.H. (1987). Our Common Future (Oxford: Oxford University Press, for the World Commission on Environment and Development).

Barton H. (2000). Conflicting perceptions of neighbourhood. In Sustainable Communities, Barton H (ed.). London: Earthscan, 3-18.

Begum, K.J.A. (2013). Electronic waste (e-waste) management in India: A review. IOSR Journal of Humanities and Social Science, 10 (4): 46-57.

Blakemore, M. and Wilson, F. (2009). MC-eGov: Study on Multichannel Delivery Strategies and Sustainable Business Models for Public Services addressing Socially disadvantaged Groups. European Commission. Retrieved from: http://ec.europa.eu/ information_society/activities/einclusion/library/studies/docs/ mc_egov_final_report.pdf

Boccaletti, G., Löffler, M. and Oppenheim, J. (2008). How IT can cut carbon emissions, The McKinsey Quarterly, October, p. 2. Retrieved from: www.mckinsey.com/clientservice/ sustainability/pdf/how_it_can_cut_carbon_missions.pdf

Burris, P. Mines, C. and Wang, N. (2011). 2012 IT Budget Planning Guide for CIOs. Forrester Research.

Centre for Energy-Efficient Telecommunications [CEET]. (2013). The Power of Wireless Cloud. Centre for Energy-Efficient Telecommunications, The University of Melbourne, Australia. Retrieved from: http://www.ceet.unimelb.edu.au/pdfs/ ceet_white_paper_wireless_cloud_jun13.pdf

Cohen, N. (1999). Greening the Internet: Ten ways e-commerce could affect the environment. Environmental Quality Management, 9 (1): 1-15.

Cormier, D. and Magnan, M. (2004). The impact of the Web on information and communication modes: the case of corporate environmental disclosure. International Journal of Technology Management, 27 (4): 393-416.

Devuyst, D. and Hens, L. (2000). Introducing and measuring sustainable development initiatives by local authorities in Canada and Flanders (Belgium): A comparative study. Environment, Development and Sustainability, 2 (2): 81-105.

du Plessis, C. (2000). Cities and sustainability: Sustaining our cultural heritage. In Cities and Sustainability: Sustaining Our Cultural Heritage, Conference Proceedings, Brandon P, Lombardi P, Perera S (eds). Sri Lanka: Kandalama.

Dunn, H.S. (2010). The Carbon Footprint of ICTs. University of the West Indies. Retrieved from: www.giswatch.org/thematicreport/sustainability-climate-change/carbon-footprint-icts

Foster, P. (2013). The EC is working with the ICT companies to measure the carbon footprint of their industry. The Green IT Review, Retrieved from: http://www.thegreenitreview.com/ 2013/03/the-ec-is-working-with-ict-companies-to.html

Gartner. (2009). Gartner estimates ICT industry accounts for 2 percent of global $\mathrm{CO} 2$ emissions. Retrieved from: www.gartner.com/it/page.jsp?id=503867

Global e-Sustainability Initiative [GeSI]. (2013). GeSI SMARTer 2020: The Role of ICT in Driving a Sustainable Future. 2 Global e-Sustainability Initiative aisbl and The Boston Consulting Group, Inc. Retrieved from: http://gesi.org/assets/js/lib/tinymce/jscripts/tiny_mce/plugins/ ajaxfilemanager/uploaded/SMARTer 2020 - The Role of ICT in Driving a Sustainable Future December 2012.pdf

Giddings, B. Hopwood, B. and O'Brien, G. (2002). Environment, economy and society: Fitting them together into sustainable development. Sustainable Development. 10, 187-196. Retrieved from: http://200.23.34.56/convocatoria/lecturas/ sustainable\%20development.pdf

Gupta, D. (2012). E- Waste: A global problem and related issues. International Journal of Scientific \& Engineering Research, 3 
(10): 1-12. Retrieved from: http://www.ijser.org/ researchpaper\%5CE--Waste-A-Global-Problem-and-relatedissues.pdf

Haigh, N.L. and Griffiths, A. (2008). E-government and environmental sustainability: Results from three Australian cases. Electronic Government: An International Journal, 5 (1): 45-62.

Hardi, P. and Zdan, T. (1997). Assessing Sustainable Development. Winnipeg: International Institute for Sustainable Development.

Hull, E.V. (2010). Poisoning the poor for profit: The injustice of exporting electronic waste to developing countries. Duke Environmental Law \& Policy Forum, 21 (1). http://scholarship.law.duke.edu/cgi/viewcontent.cgi?article $=1$ 038\&context $=$ delpf

Info-communications Development Authority of Singapore [iDA]. (2012). Co-creating the Future InfoCom Technology Roadmap 2012: ICT and Sustainability. Info-communications Development Authority of Singapore. Retrieved from: http://www.ida.gov.sg/ /media/Files/Infocomm\%20Landsca pe/Technology/TechnologyRoadmap/ICTandSustainability.pdf

International Energy Agency [IEA]. (2009). Gadgets and Gigawatts: Policies for Energy Efficient Electronics. France, Retrieved from: http://www.iea.org/publications/freepublications/publication/ gigawatts2009-1.pdf

International Council for Local Environmental Initiative [ICLEI]. (1996). The Local Agenda 21 Planning Guide: An Introduction to Sustainable Development Planning. Toronto: ICLEI

International Telecommunication Union [ITU]. (2009). ICTs and Climate Change, background paper for the ITU Symposium on ICTs and Climate Change, Quito, Ecuador, 8-10 July.

International Union for Conservation of Nature [IUCN]. (2012). The Future of Sustainability: Re-thinking Environment and Development in the Twenty-first Century. Retrieved from: http://cmsdata.iucn.org/downloads/iucn_future_of_sustanabil ity.pdf

Jens Schippl, J. and Weinberger, N. (2008). Assessing the Potential of ICT to Increase Energy Efficiency and Fight Climate Change-Key Technologies and Prospects. European Parliament, Retrieved from: http://www.itas.fzk.de/deu/lit/ 2009/scwe09a.pdf

Krishnan, S. and Teo, T. (2011) Moderating Effects of Environmental Factors on E-Government, E-Business, and Environmental Sustainability (December 6, 2011). ICIS 2011 Proceedings. Paper 2. Retrieved from: http://aisel.aisnet.org/icis2011/proceedings/ebusiness/2

Kuhndt, M., von Geibler, J., Turk, V., Moll, S., Schallaböck, K. and Steger, S. (2003). Virtual Dematerialisation: Ebusiness and Factor X: Final Report: Forum for the Future. Retrieved from: http://www.ecotic.es/files/Informe_ebusiness_and_factor_x.pdf

Kumar, R. and Best, M.L. (2006). Impact and Sustainability of EGovernment Services in Developing Countries: Lessons Learned from Tamil Nadu, India. The Information Society, 22: 1-12. Retrieved from: http://mikeb.inta.gatech.edu/papers/ infosoc.egov.kumar.best.pdf

Labelle, R., Rodschat, R. and Vetter, T. (2008). ICTs for eEnvironment Guidelines for Developing Countries, with a Focus on Climate Change, International Telecommunication Union, Geneva, Switzerland. Retrieved from: http://www.itu.int/ITU-D/cyb/app/docs/itu-icts-for-eenvironment.pdf

Liu, X.B., Tanaka, M. and Matsui, Y. (2006). Generation amount prediction and material flow analysis of electronic waste: A case study in Beijing, China. Waste Manag Res, 24: 434-45.

Luther, L. (2010). Managing Electronic Waste: Issues with Exporting E-Waste. Retrieved from: http://www.fas.org/sgp/crs/misc/R40850.pdf

Mansell, R. (2012). ICT Innovation and Sustainable Development. The International Institute for Sustainable Development. Retrieved from: http://www.iisd.org/pdf/2012/ com_icts_mansell. pdf
Matthews, H.S. (2001). The Environmental Implications of the Growth of the Information and Communications Technology Sector, paper for Environment Directorate, OECD, Paris, 2001.

Nishant, R., Teo, T.S.H. and Goh, M. (2013). Understanding the Environmental Impact of Sustainable IT: An Empirical Examination. Proceedings of the 18th Pacific Asia Conference on Information Systems (PACIS 2013), Jeju Island, Korea, June 18-22 Retrieved from: http://www.pacisnet.org/file/2013/PACIS2013-094.pdf

OECD (2011) Government at a Glance. Organisation for Economic Co-operation and Development (OECD). Retrieved from: http://www.oecd.org/inclusive-growth/Government\%20at \%20a\%20Glance\%202011.pdf.

Ogbomo, M.O., Obuh, A.O. and Ibolo, E. (2012) Managing ICT Waste: The Case of Delta State University Abraka, Nigeria. Library Philosophy and Practice 2012, Retrieved from: http://www.webpages.uidaho.edu/ mbolin/obuh-ogbomoibolo.htm

Quintiliani, A. Chinnici, M., Kolentini, E., Racoviţan, I., Ionescu, I., Destree, K., ... Chebbo, M. (2010). ICT and Environment Protection: Report on ICT requirements, offers and needs. European Commission within the ICT Policy Support Programme. Retrieved from: http://seesgen-ict.rseweb.it/content/files/documents/Deliverables/Deliverable 20D6-2 20R0-1.pdf

Robinson, B.H. (2009). E-waste: An assessment of global production and environmental impacts. Science of the Total Environment, 408, 183-191.

Schluepa, M., Hageluekenb, C., Kuehrc, R., Magalinic, F., Maurerc, C., Meskersb, C., ... Wangc, F. (2009). Recycling-from Ewaste to Resources. United Nations Environment Programme \& United Nations University. Retrieved from: http://www.unep.org/pdf/pressreleases/Ewaste_publication_screen_finalversion-sml.pdf

Souter, D., MacLean, D. and Creech, H. (2013) Towards Knowledge Societies for Peace and Sustainable Development. UNESCO Conference Paris 25-27 February 2013. Retrieved from: http://ictstheinternetandsustainability.wordpress.com/

Sthiannopkao, S and Wong, M.H. (2012). Handling e-waste in developed and developing countries: Initiatives, practices, and consequences. Sci Total Environ, vol (issue): xx-yy.

Strange, T. and Bayley, A. (2008) Sustainable development: Linking economy, society, and environment. OECD Publishing. Retrieved from: http://www.oecdilibrary.org/docserver/download/0108121e.pdf?expires=1374 871268\&id=id\&accname=guest\&checksum=D7E1A6C9EC4 9B00AD295E3A6B1AB4659

United Nations [UN]. (2005). World Summit Outcome, Resolution A/60/1, adopted by the General Assembly on 15 September 2005, Retrieved from: http://data.unaids.org/Topics/ UniversalAccess/ worldsummitoutcome_resolution_24oct2005 en.pdf

United Nations Environment Programme [UNEP]. (2009). Recycling - from e-waste to resources-solving the e-waste problem. Sustainable innovation and technology transfer industrial sector studies. United Nations Environment Programme. Retrieved from: http://www.unep.org/PDF/Press Releases/E-Waste_publication_screen_FINALVERSIONsml.pdf

United States (U.S.) Environmental Protection Agency. [Online]. Available from: http://www.epa.gov/epawaste/conserve/ materials/ecycling/manage.htm. Retrieved 2012-03-13.

Vickery, G. (2012). Smarter and Greener: Information Technology and the Environment: Positive or Negative Impacts? The International Institute for Sustainable Development. Retrieved from: http://www.iisd.org/pdf/2012/com_icts_vickery.pdf

Zadek, S. (2011). Green growth's invisible ingredient. China Dialogue. Retrieved from: www.chinadialogue.net/ article/ show/single/en/4163-Green-growth-s-invisible-ingredient 